\title{
THE APPLICATIONOF ANDRAGOGICAL PRINCIPLES IN EDUCATION AND TRAINING
}

\author{
Mansur \\ Education Quality Assurance Agency of Maluku Province \\ mansurarsyad@yahoo.com
}

\begin{abstract}
The aim of this research is to obtain an objective and comprehensive pictures about the results of applying the andragogical principles in the implementation of education and training. This research used evaluation research method with Stake's Responsive Evaluation Model. The subject of this research is the training participants, training committees, facilitators, teacher trainers, and the training program supervisor. The data were collected through interview techniques, focus group discussion, observation, questionnaire, and document study.The results of this research showed that some of the component has met the criteria in the implementation of the program, but most of the component andother training aspects require further development. The fundamental weaknesses of the training implementations wereinadequate understanding of the conceptual of the facilitator's to the adult learning principles. This hasimplicationsforthe whole training process and results achieved. However, the summary comes up to a conclusion that the implementation training at Educational Quality Assurance Institution of Maluku Province still need improvement, especially the aspect of application of adult learning principles.
\end{abstract}

Keywords: AndragogicalPrinciples, Stake's Responsive Evaluation Model.

Education and training (training) is a requirement in the development of an organization. The problem is how to build an effective training program. Answering the question requires comprehensive planning. While the facts show the implementation of the training especially in the national education environment more on aspects of content and other aspects. One of the apes that has not been integrated in the preparation of training programs is the principles of adult learning (andragogy). Essentially feel the principles of adult learning inherent in every training activity because on the part of the training is a form of formal adult education. For that situation lessons where factors - factors that are "coincidental" and inefficient can be minimized. This is emphasized by Merriam and Cunningham (1989: 18) and Knowles (1980: 54) that in adult learning, from learning materials should be arranged sequences that are not oriented to the subject, slow to the problem. The emphasis on the orientation according to Jarvis (1990: 126) implies the role and responsibility of the facilitator in the learning process. The various studies presented by Darkenwald and Knox (1984: 20) which essentially hold the method method chosen must be in accordance with the purpose and context.

Basically, the training program should ideally consider the characteristics of the training participants as adults (based on chronological age) and also from the psychological aspect. Thus, understanding the concept and correct implementation of the principles of adult learning synergized with other educational instruments is expected to further optimize the achievement of the goals and objectives of the training

Training as part of adult education in the formal form requires a good planning and implementation in accordance with the characteristics of adult education. In fact, the implementation of education and culture training through the Education Quality Assurance Agency (LPMP) as a technical implementation unit of the ministry of education in the regions has not been followed by a control 
mechanism in the form of formal evaluation. Moreover, more specific aspects such as the application of the principles of andragogy are not at all a concern both by the ministry of education and by LPMP itself as the executor of the program. So related to that this research explores the issue as the focus of evaluation with the problem of research that is how the application of adult learning principles in planning and implementation in the Quality Assurance Institute of Education Maluku Province?

\section{METHOD}

This study aims to evaluate the application of the principles of andragogy or adult learning in the implementation of education and training by evaluatively evaluating the overall major components of education and training in the perspective of adult learning.

The subjects of this study are the providers of training programs, facilitators and training participants, including alumni of training participants. This research was developed in a qualitative paradigm, using Stake's model evaluation research method, Responsive Evaluation Model. The Responsive Model according to Stake (1983: 292), Guba (1987: 60), Fitzpatrick, Sanders and Worthen (2004: 136), Stufflebeam and Shinkfield (2007: 212-213) emphasize the process approach with clientcentered), and directly oriented to the activities of the program. However, for the macro picture the research data also includes quantitative data collected through questionnaires. For that selected the respondents are divided into two groups. The first group are those who follow the training facilitated by LPMP but the activities are carried out in the core school or work center of the teacher work group. This group consists of 120 people consisting of 60 alumni of training and 60 people who are following the training activities. As for the respondents in the second group of training participants who follow the training activities conducted in LPMP which number 180 people. To both groups are given different questionnaires. The difference is in the indicator which in the first group is not asked about the facilities and infrastructure of the training and service committee because it is outside the LPMP authority and all facilities and its operations are handled directly by each work group.

Furthermore, for qualitative data, data collection is done through in-depth interviews, participatory observation and program document review. The analysis for qualitative data using Model Miles and Huberman (1992: 19), with the focus of evaluation is the planning of training, teaching materials and the implementation of learning in terms of applying the principles of andragogy. As for the quantitative data analysis using descriptive statistics is the percentage of respondents' answers by category defined. The criteria that are used are at least 75 percent of participants expressed satisfaction for every aspect that is evaluated.

\section{RESULT}

Evaluation results at the planning stage of education and training show that the planning aspect of the training program still has weaknesses. The root of the problem is that the education and training programs in the educational quality assurance institution are still top-down models. The analysis of the training program planning implemented in LPMP is as shown in the table below: 
Table 1 Analyzed Analysis of Application of Andragogical Principles in Training Planning.

\begin{tabular}{|c|c|c|c|c|c|}
\hline No & $\begin{array}{l}\text { Aspects } \\
\text { analyzed }\end{array}$ & $\begin{array}{l}\text { Relevant } \\
\text { principles }\end{array}$ & $\begin{array}{l}\text { Condition } \\
\text { /Problems }\end{array}$ & Impact & Alternative Solutions \\
\hline \multirow[t]{2}{*}{1} & \multirow[t]{2}{*}{$\begin{array}{l}\text { Training } \\
\text { Needs } \\
\text { Analysis( } \\
\text { TNA) }\end{array}$} & \multirow[t]{2}{*}{$\begin{array}{l}\text { - Goal } \\
\text { Oriented } \\
\text { - Relevancy } \\
\text { oriented }\end{array}$} & $\begin{array}{l}\text { The training } \\
\text { program is not } \\
\text { based on needs } \\
\text { analysis } \\
\text { especially } \\
\text { related to adult } \\
\text { learning }\end{array}$ & $\begin{array}{l}\text { Difficulties in } \\
\text { realizing the } \\
\text { relevance between } \\
\text { the needs of the } \\
\text { participants in } \\
\text { particular and the } \\
\text { needs of the } \\
\text { training in general } \\
\text { with the given } \\
\text { training program. }\end{array}$ & $\begin{array}{l}\text { It is necessary to map through } \\
\text { the Training Need Analysis } \\
\text { (TNA) mechanisms for training } \\
\text { needs including the experience } \\
\text { and learning needs of } \\
\text { participants in the training } \\
\text { program so that the objectives, } \\
\text { patterns, and materials of the } \\
\text { training program are really } \\
\text { appropriate to the needs of the } \\
\text { participants. }\end{array}$ \\
\hline & & & $\begin{array}{l}\text { - Training } \\
\text { program } \\
\text { is still top- } \\
\text { down model } \\
\text { - There is no } \\
\text { review of } \\
\text { draft } \\
\text { program } \\
\text { design }\end{array}$ & $\begin{array}{l}\text { - Service training } \\
\text { program is } \\
\text { uniform } \\
\text { - Unaccompanied } \\
\text { problems and } \\
\text { needs of } \\
\text { educational } \\
\text { development and } \\
\text { educational } \\
\text { personnel in areas } \\
\text { that are varied }\end{array}$ & $\begin{array}{l}\text { - Need to build a training } \\
\text { program development system } \\
\text { with a buttom-up model to } \\
\text { guarantee the relevance of } \\
\text { training programs in LPMP } \\
\text { with the problems and needs } \\
\text { of each education unit in the } \\
\text { region. } \\
\text { - The design of the training } \\
\text { program needs to be reviewed } \\
\text { to see its compatibility with } \\
\text { adult learning characteristics }\end{array}$ \\
\hline \multirow[t]{2}{*}{2} & \multirow[t]{2}{*}{$\begin{array}{l}\text { Recruitme } \\
\mathrm{nt} \quad \text { of } \\
\text { Training } \\
\text { Participan } \\
\text { ts }\end{array}$} & \multirow[t]{2}{*}{$\begin{array}{l}\text { - } \text { Goal } \\
\text { Oriented } \\
\text { - Relevancy } \\
\text { oriented }\end{array}$} & $\begin{array}{l}\text { - Information } \\
\text { delays and } \\
\text { transportation } \\
\text { constraints for } \\
\text { participants in } \\
\text { remote areas }\end{array}$ & 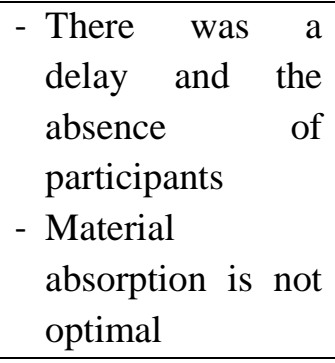 & $\begin{array}{l}\text { - Need anticipation with a more } \\
\text { efficient information system } \\
\text { - Coordination between LPMP } \\
\text { and District / Town Education } \\
\text { office needs to be developed } \\
\text { in anticipation of training } \\
\text { information in LPMP. }\end{array}$ \\
\hline & & & $\begin{array}{l}\text { - There is no } \\
\text { clarity } \\
\text { regarding the } \\
\text { completeness } \\
\text { of the } \\
\text { materials, } \\
\text { tools and } \\
\text { criteria of the } \\
\text { participants }\end{array}$ & $\begin{array}{l}\text { - Difficulties for } \\
\text { the participants to } \\
\text { adjust their } \\
\text { learning } \\
\text { readiness } \\
\text { - Difficulties for } \\
\text { facilitators in } \\
\text { developing } \\
\text { methods }\end{array}$ & $\begin{array}{l}\text { - Need to build commitment } \\
\text { between LPMP and education } \\
\text { offices to consistently refer to } \\
\text { the requirements criteria of } \\
\text { participants } \\
\text { - Coordination between } \\
\text { facilitator and training manager } \\
\text { is needed to identify the } \\
\text { learning needs }\end{array}$ \\
\hline
\end{tabular}


Table 1 describes the problem of planning of training program in LPMP both technically that is recruitment of training participants and substantively that is related to requirement analysis of training. The analysis of trainer plan as presented in table 1 macro can be seen from the participants' results, as shown in figure 1 below:

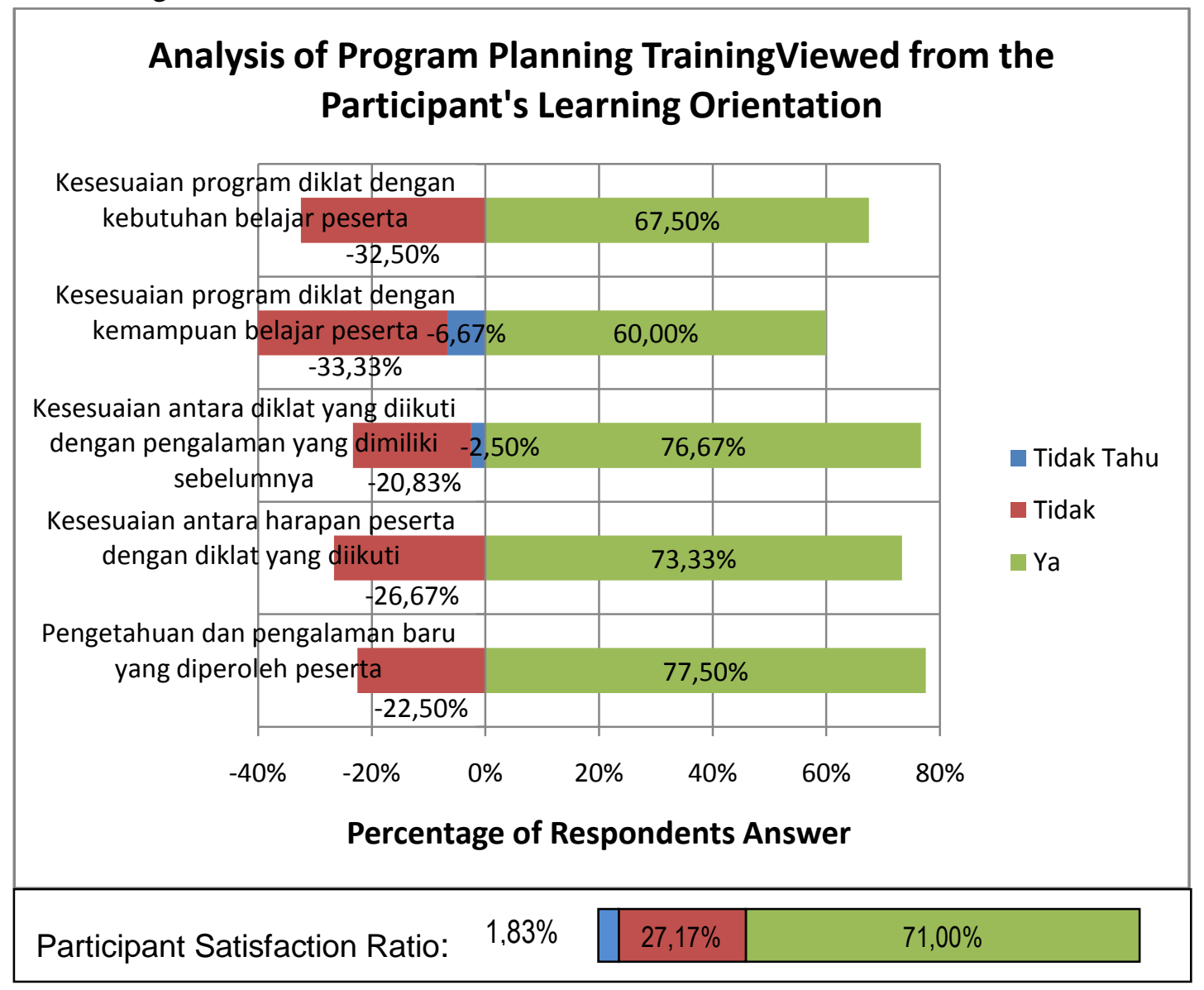

Figure 1 Graph of Planning Program Appraisal Analysis Based on Participant Learning Orientation 
Figure 1 shows that the participants are quite appreciative of the training program especially related to the new knowledge and experience they get through the following training program. On the contrary, the percentage of suitability of the training program with the participants' learning ability is far below the criteria. This means there is a difficulty for participants to adjust their level of ability with the training program. Thus it should be a record for the training managers and especially for the facilitator that although the training program is in accordance with the expectations of the participants but substantively still need to be studied both in terms of materials and development in the learning process. Overall average achievement of planning aspects of this training does not meet the criteria of 71 percent.

The next component is the implementation of the training program. These components include the readiness of learning materials, the ability of the facilitator and their attitudes and behaviors in facilitating learning. The following is an analysis of teaching materials / training materials that are based on the answers of respondents / alumni of training participants. If the respondent's answer is categorized into two: "No" and "Do not know" is the first category while the answer "Yes" is the second category then the proportion of answers is shown in figure 2 below:

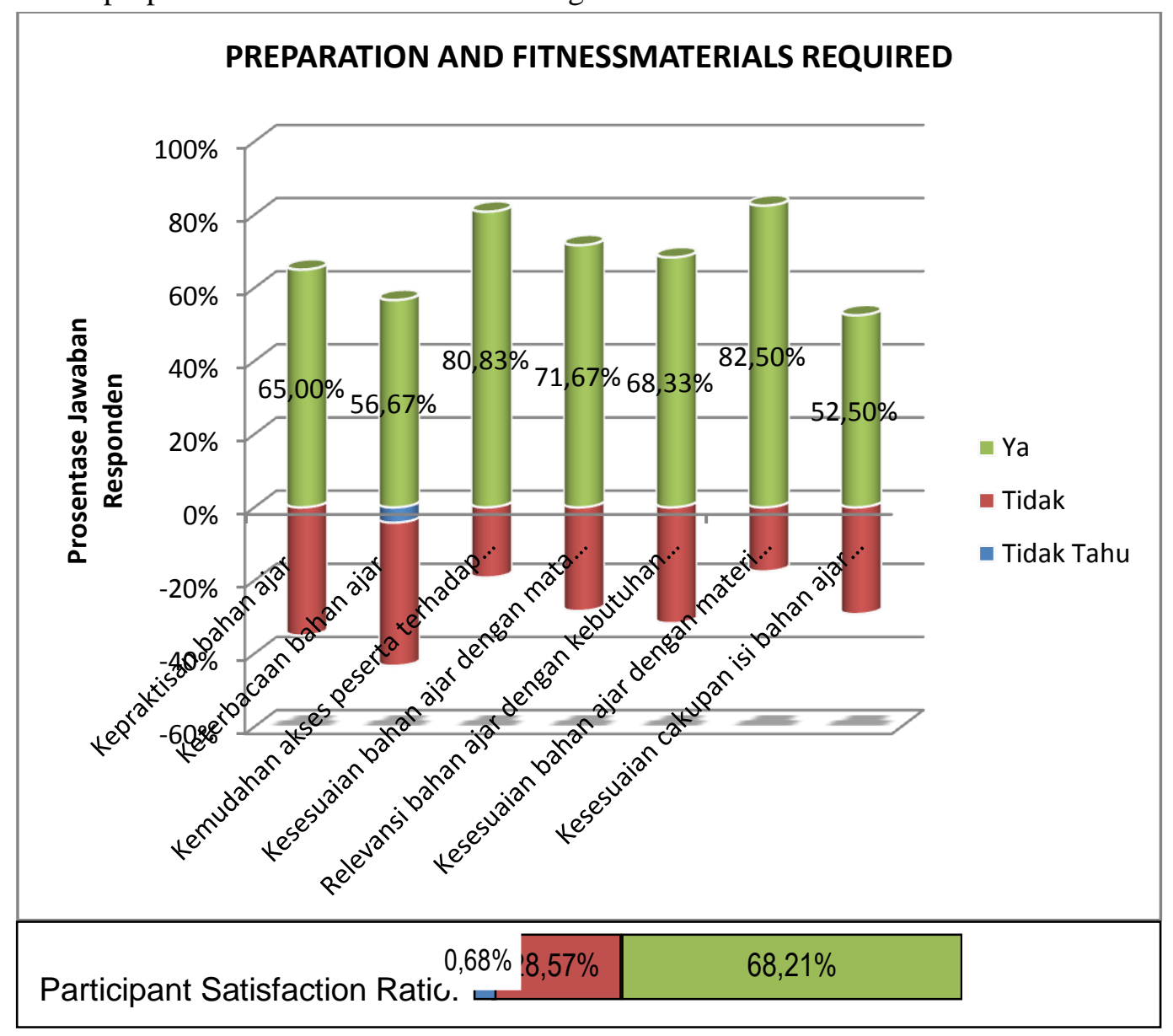

Figure 2Adicipation of Participants on the Readiness and Conformity of Training Materials

In Figure 2, the stem section on the abscissal line 0 percent and above shows the proportion of participants who definitely give a positive appreciation of the quality of teaching materials. While the stem part below the 0 percent abscissa line depicts the proportion of participants or respondents who are hesitant or have a negative perception of the quality of training materials. Overall, the suitability or preparedness of teaching materials has not reached the criteria set. However, there are 2 (two) aspects 
that are fulfilled namely the participants' access to all teaching materials and the conformity of teaching materials with the material presented by the facilitator. The two aspects are 80.83 percent and 82.50 percent respectively. This means that most participants do not question their access to all teaching materials.

Similarly, regarding the suitability of teaching materials with the material provided by the facilitator. With the figure 82.50 percent can be concluded that in the views of the participants, the facilitator is quite consistent with the teaching materials and the material presented. Figure 2 also shows that the suitability of the range of teaching materials with participants' expectations is the lowest of 52.50 percent, slightly adrift below the literacy aspect of the teaching materials.

The coverage in question is the depth and breadth of the material. The question of this aspect intends to reveal the participants' judgment as to whether the breadth and depth of the training materials is sufficient compared to what they expect from the material. The following is presented the results of the readiness analysis and the suitability of teaching materials based on the results of the analysis of training materials reviewed from the principle of andragogy. 
Table 2 Analysis of Application of Andragogical Principles Reviewed from Training Material

\begin{tabular}{|c|c|c|c|c|c|}
\hline No. & $\begin{array}{l}\text { Aspects } \\
\text { analyzed }\end{array}$ & $\begin{array}{l}\text { Relevant } \\
\text { principles }\end{array}$ & $\begin{array}{l}\text { Conditions/ } \\
\text { Problems }\end{array}$ & The impact & Alternative Solutions \\
\hline \multirow[t]{3}{*}{1} & \multirow[t]{3}{*}{$\begin{array}{l}\text { Substance } \\
\text { Material }\end{array}$} & \multirow[t]{3}{*}{$\begin{array}{l}\text { - Relevancy } \\
\text { oriented } \\
\text { - Practical } \\
\text { - Goal } \\
\text { Oriented }\end{array}$} & $\begin{array}{l}\text { Unconformity } \\
\text { between } \\
\text { objectives and } \\
\text { materials, } \\
\text { material scope } \\
\text { and scopeSome } \\
\text { materials are not } \\
\text { practical enough }\end{array}$ & $\begin{array}{l}- \text {-Inadequate } \\
\text { material coverage } \\
\text { to achieve } \\
\text { objectives is } \\
\text { expected to be } \\
\text { achieved by the } \\
\text { participants. }\end{array}$ & $\begin{array}{l}\text { Substance and coverage } \\
\text { of training materials } \\
\text { should be developed with } \\
\text { reference to the } \\
\text { established training } \\
\text { objectives. A joint study } \\
\text { is needed between the } \\
\text { training program manager } \\
\text { and the facilitator team } \\
\text { based on the needs } \\
\text { analysis of the training. }\end{array}$ \\
\hline & & & $\begin{array}{l}\text { There is still a } \\
\text { very theoretical } \\
\text { material and is } \\
\text { lacking with the } \\
\text { necessary } \\
\text { examples and } \\
\text { illustrations }\end{array}$ & $\begin{array}{l}\text { Difficulties for } \\
\text { participants to } \\
\text { apply further in } \\
\text { accordance with } \\
\text { the needs of their } \\
\text { tasks and work }\end{array}$ & $\begin{array}{l}\text { Need the development of } \\
\text { training materials more } \\
\text { practical.Facilitators need } \\
\text { to elaborate more } \\
\text { theoretical materials } \\
\text { become more contextual } \\
\text { and understandable to } \\
\text { participants }\end{array}$ \\
\hline & & & $\begin{array}{lr}\text { Some materials } \\
\text { have } & \text { low } \\
\text { readability } & / \\
\text { digestibility }\end{array}$ & $\begin{array}{l}\text { The participants' } \\
\text { absorbance of the } \\
\text { material is } \\
\text { inadequate } \\
\text { because their } \\
\text { capacity does not } \\
\text { match the } \\
\text { complexity of the } \\
\text { material }\end{array}$ & $\begin{array}{l}\text { The development of } \\
\text { materials or teaching } \\
\text { materials needs to be } \\
\text { adjusted to the } \\
\text { educational background } \\
\text { and the capacity of the } \\
\text { participants so that the } \\
\text { effectiveness of the } \\
\text { training process and } \\
\text { outcomes can be achieved } \\
\text { optimally }\end{array}$ \\
\hline 2 & $\begin{array}{l}\text { Completeness } \\
\text { of Teaching } \\
\text { Material } \\
\text { Components }\end{array}$ & $\begin{array}{l}\text { Goal } \\
\text { Oriented }\end{array}$ & $\begin{array}{l}\text { Completeness of } \\
\text { components is } \\
\text { still problematic } \\
\text { because in } \\
\text { general not } \\
\text { equipped with } \\
\text { evaluation } \\
\text { component of } \\
\text { learning } \\
\text { outcomes }\end{array}$ & $\begin{array}{l}\text { Participants do not } \\
\text { get enough } \\
\text { opportunity to do } \\
\text { self-evaluation } \\
\text { (self evaluation) to } \\
\text { what they have } \\
\text { gained in learning. }\end{array}$ & $\begin{array}{l}\text { The facilitator needs to } \\
\text { prepare enough exercises } \\
\text { (tasks / activities) that } \\
\text { need to be done } \\
\text { independently as a } \\
\text { reinforcement of the } \\
\text { concept that has been } \\
\text { given to participants, } \\
\text { especially materials that } \\
\text { are modular. }\end{array}$ \\
\hline
\end{tabular}


In addition to teaching materials or materials, the learning atmosphere also contributes to the adult learning process. In general, the participants' appreciation of the learning atmosphere in LPMP can be seen in Figure 3 below:

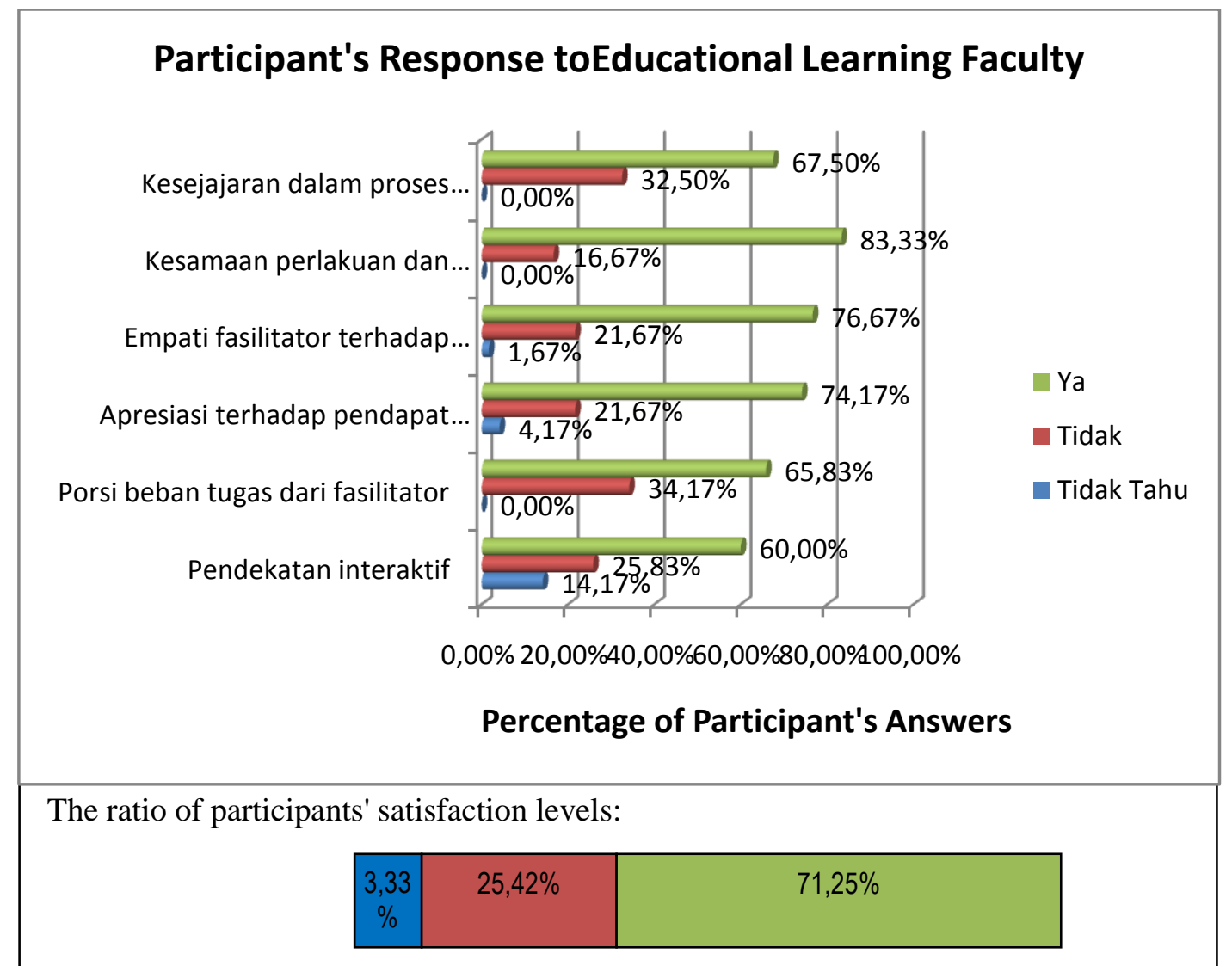

Figure 3Apresented Participants on the Learning and Training Atmosphere Figure 3 generally shows that the level of participants' satisfaction with the learning atmosphere in the training that they had followed was positive, reaching 71.25 percent although not yet fulfill the criteria. Aspects that get the highest appreciation is the similarity of treatment / attention given by the facilitator with the percentage reached 83.33 percent. While the lowest assessed aspect is the interactive approach with 60,00 percent answer percentage. This means that there are still many trainees who assess the facilitator has not succeeded in developing an interactive approach in the learning process. The participant's appreciation of further facilitator performance can be summarized in the profile as outlined in the following table.

Table 3 Criterion Compliance Profile for Aspects of Facilitator Training Capability

\begin{tabular}{|c|l|c|c|c|c|}
\hline \multirow{2}{*}{ No. } & \multirow{2}{*}{ Aspect } & \multicolumn{2}{|c|}{ Standard Used } & \multicolumn{2}{c|}{ Standard Raised } \\
\cline { 3 - 6 } & & \multicolumn{2}{|c|}{ Fulfilled } & \multicolumn{2}{|c|}{ Fulfilled } \\
\cline { 3 - 6 } & & Yes & No & Yes & No \\
\hline 1 & Mastery of learning materials & $\sqrt{ }$ & & & $\sqrt{ }$ \\
\hline 2 & Application of learning method & $\sqrt{ }$ & & & $\sqrt{ }$ \\
\hline 3 & Systematic presentation & $\sqrt{ }$ & & & $\sqrt{ }$ \\
\hline 4 & Ability to respond to participants' questions & & $\sqrt{ }$ & & $\sqrt{ }$ \\
\hline
\end{tabular}




\begin{tabular}{|l|l|c|c|c|c|}
\hline 5 & Use of learning tools / media & $\sqrt{ }$ & & & $\sqrt{ }$ \\
\hline 6 & Language usage & $\sqrt{ }$ & & $\sqrt{ }$ & \\
\hline
\end{tabular}

Table 3 shows that if using LPPL standard for this category is "Enough Satisfied" then all criteria are met except motivation to the participants. This means that only one criterion is not met. This situation is inversely proportional to the standard being raised to the "Satisfied" category. With these categories then almost all aspects do not meet the criteria except the use of language. Thus it is clear that if LPMP Maluku is committed to improving the quality of the training implementation services, it is necessary to develop a special program for capacity building of its facilitators.

\section{DISCUSSION}

First, the planning component of the training. The results showed that the planning component of the training still showed some weaknesses. Though this component should be strategically positioned in adult learning. The planning component is related to the participants 'learning readiness, the relevance of the training program to their learning needs, and the participants' expectations of the training program they attend. All of these are aspects that really determine the process and the results of the training.

Theories about adult learning emphasize the readiness of learning and experience as a basis for developing knowledge through learning. The purpose of adult education education as emphasized by Knowles (1980: 19) is based on two basic principles: 1) the learners are basically taking direction for how to be better, and 2) the learners also want to know how their knowledge can bring benefits. The concept is the foundation of the idea of the importance of designing training programs based on the needs of participants. The results of the study (2006) reported that consistency of application of the principles of andragogy in the training to make participants can maintain and apply what they have learned in the workplace they.

Second, the readiness and suitability of teaching materials. The challenges faced by facilitators in adult learning, especially with regard to these teaching materials are quite unique. On the one hand, teaching materials are required not to be teroretis (easy to understand) but on the other hand also emphasize the exposure of logical material and not "perfunctory". That is what requires the sensitivity of the facilitator or author of the teaching materials to package the teaching materials that have a high level of digestibility, logical and practical.

Third, the implementation of the learning process The presence of facilitators is very influential on the adult learning process so required not only the mastery of the material dish but also the whole understanding and experience of adult learning. Although the initial assumption was that the facilitator had a certain amount of knowledge and experience expected more than the studying population but that was not enough to get the participants to behave in class but facilitators' attitude was important. Therefore, the manager of the training program and especially the facilitator really need to understand that in the learning process for adults, these three aspects can be described as learning triangle that is, the ability to facilitate, the atmosphere of learning and the attitude / behavior of the facilitator. All three can support each other but when one of them fails then the other will be directly affected. Mature planning coupled with good mastery of material is not absolutely able to go well in accordance with the expectations of the facilitator. So in adult learning, it is important to always keep the rhythm and learning atmosphere.

The essence of Andragogi's process according to Jones (1988: 161) one of them is continuous negotiation. Thus a facilitator should place participants as learning partners while avoiding insistence, so with a continuous negotiation model. Therefore, the facilitator should have a strong understanding that every adult who attends a training activity, each has different trends and expectations. The higher 
the participants' expectations, the more difficult the facilitator will be to meet those expectations. With the negotiation model, the facilitator can know what the participants hope and how to make it proportionally through the training program they attend.

Thus, participatory planning is required. Although only limited to the discussion of learning scenarios, at least participants are given the opportunity to convey their perspective on the overall learning process to be followed. Thus, the opportunity to get closer to the participants' expectations with training activities can work better without completely changing the scenario that the previous facilitator has designed.

Associated with pengeloalan learning process, especially for adults, more can be seen from the results of review conducted by Brookfiled (1989: 202) from several research results that highlight the problem of facilitators in learning. The results of the review concluded that in facilitating adults, the facilitator should seek to develop meta-learning and self-reflection of a learner and not simply transmit material content.

The perspective presented above is basically consistent with the results of this study which recommended the importance of reorientation of learning for adult-centered adults. The results of other analyzes related to the above perspective are as described by Blondy (2007) that in a training activity, the facilitator should be able to empower the participants to be actively involved as the same person and respect each other with their facilitators as well as with the facilitators as well as to explore the participants' experiences and their involvement optimally in every stage of learning is an important part in the adult learning process.

\section{CONCLUSION}

Application of the principles of andragogy in the implementation of education and training shows the achievement of criteria on some aspects but most of the components and other aspects of the training need further development. The design of a top-downmodel training program does not provide space for participation for stakeholders, which is particularly emphasized in the principles of andragogy. Another problem is the lack of understanding of training managers, especially the facilitators of the concept of adult learning that impact on the planning and implementation of the program as a whole.

\section{REFRENCES}

Blondy, Laurie C. (2007). "Evaluation and Application of Andragogical Assumptions to the Adult Online Learning Environment," Journal of Interactive Online Learning. Vol. 6 No. 2, Summer.

Brookfiled, Stephen D. (1989)."Facilitating Adult Lerning" In: Sharan B. Merriam and Phyllis M. Cunningham (eds.) Handbook of Adult and Continuing Education. Washington, D.C.: American Assosiation for Adult and Continuing Education.

Darkenwald, Gordon G., dan Alan B. Knox. (1984).Meeting Educational Needs of Young Adults. San Fransisco: Jossey-Bass.

Fitzpatrick, Jody L., J. R. Sanders,dan B. R. Worthen. (2004). Program Evaluation: Alternative Approaches and Practical Guidelines. Boston: Pearson Education.

Guba, Egon G. (1987).Menuju Metodologi Inkuiri Naturalistik Dalam Evaluasi Pendidikan, terjemahan S. Zanti Arbi. Jakarta: Djambatan.

Jarvis, Peter. (1990).Adult and Continuing Education Theory and Practice. New York: Nichols Publishing Company.

Jones, David. (1988). Adult Education and Cultural Development, London: Guilford and King's Lym. 
Knowles, Malcom S. (1980). The Modern Practice of Adult Education: From Pedagogy to Andragogy. Chicago: Follet Publishing Company.

Merriam, Sharan B., dan Phyllis M. Cunningham. (1989).Handbook of Adult and Continuing Education. Washington, D.C.: American Assosiation for Adult and Continuing Education.

Miles, Matthew B., dan A. Michael Huberman. (1992).Analisis Data Kualitatif, terjemahanTjetjepRohendiRohidi. Jakarta: UI-Press.

Stake, Robert E. (1983). "Program Evaluation, Particulary Responsive Evaluation." In: Madaus, ScrivendanStufflebeam (eds.), Evaluation Models.Massachusetts: Kluwer Academic Publisher, 1983.

Stufflebeam, Daniel L., dan Antony J. Shienkfield. (1985).Systematic Evaluation. Boston: KluwerNijhoffPublihing,

Ota, Carrie, Cynthia F. DiCarlo, Diane C. Burts, Robert Laird, dan Cheri Gioe. (2006).“Training and the Needs of Adult Learners," Journal of Extension. Vol. 44 No. 6, Desember. 